DOI: http://doi.org/10.21698/simi.2018.fp09

\title{
NUMERICAL MODELING OF FLOW OVER AN OGEE SPILLWAY AND INVESTIGATION OF EFFECT OF DOWNSTREAM INFLUENCES ON DISCHARGE
}

\author{
$\underline{\text { Ali Yıldız }}{ }^{1}$, Alpaslan Yarar ${ }^{1}$, Şerife Yurdagül Kumcu² \\ ${ }^{1}$ Selcuk University Civil Engineering Department, 369 Akademi Mah. Yeni Istanbul Cad., \\ 42130, Selcuklu-Konya, aliyildiz@sekcuk.edu.tr, ayarar@selcuk.edu.tr, Turkey \\ ${ }^{2}$ N. Erbakan University Civil Engineering Department, yudagulkumcu@gmail.com, Turkey
}

\begin{abstract}
The main aim of this study was to investigate flow over an ogee spillway and simulating by numerical model. A commercially available computational fluid dynamics (CFD) program, which solves the Reynolds-averaged Navier-Stokes equations (RANS), was used to model the physical model setup. Flow over an ogee spillway has free surface and turbulent flow so that in some cases calculating flow rate and flow depths are difficult. Increasing in water level at downstream may cause reduce in discharge because of suction forces and negative pressure. In this study, different numerical turbulence models are used to predict discharge and compared with experimental results. In experiments, discharge and flow depths of physical model were recorded for 22 different total head over the crest. The results show that there is reasonably good agreement between the physical and numerical models for discharges.
\end{abstract}

Keywords: degree of submergence, downstream influence, numerical modeling, Ogee spillway

\section{Introduction}

Dams are built for water storage, floods control and energy production. Generally a dam construction consists of foundation, body, dam reservoir, spillway, bottom outlet and water intake structures. Spillways are one of the most important dam structures in terms of dam safety. Spillways transfer excess water, coming to the dam reservoir, to the downstream safely without damaging dam and other structures. Many failure of dams have been caused by improperly designed spillway are insufficient spillway capacity (Bradley 1952). Hydraulic design of the spillways is done with some graphical and analytical methods. In some cases design of the spillways is made with physical models. At design stage of hydraulic structures, the small-scaled physical models are constructed to observe the behavior of water and determine the problems that may be encountered. However, preparing physical tests models requires professional labor work. Moreover, experimental studies may be more expensive, take longer time and have scale effect.

Although the main reason for the need for dams do not vary past today, significant steps were achieved in dam construction by progressive engineering techniques and computer technologies. Computational Fluid Dynamics (CFD) is a type of numerical modeling technique developed to solve fluid mechanics problems. CFD investigates 


\section{INTERNATIONAL SYMPOSIUM "THE ENVIRONMENT AND THE INDUSTRY", SIMI 2018, PROCEEDINGS BOOK}

fluid-fluid and fluid-solid interactions behavior. Applicability of CFD to spillway design is great advantage of hydraulic engineering due to its features (Cederstorm 1998). Although solution of numerical models take a long time in the computer, results such as free surface profile, velocity and discharge which cannot be obtained from one and two dimensional models can be easily examined in 3-Dimensional models. CFD can be used in many areas where fluid flow is present.

\section{Materials and Methods}

\section{Ogee spillway design}

The relationship of the ogee crest coefficient, $\mathrm{C}_{0}$, to various values of $\mathrm{P} / \mathrm{H}$, is shown on Figure 1. These coefficients are valid only when the ogee is formed to the ideal naple shape; that is, when $\mathrm{H}_{\mathrm{e}} / \mathrm{H}_{\mathrm{o}}=1$ (Maynord 1985). Discharge coefficient ratio $\mathrm{C} / \mathrm{C}_{\mathrm{o}}$ continues to increase with $\mathrm{H}_{\mathrm{e}} / \mathrm{H}_{\mathrm{o}}$ (as shown in Figure 1 ) up to maximum value of head ratio $\left(\mathrm{H}_{\mathrm{e}} / \mathrm{H}_{\mathrm{o}}\right)$. With a narrower crest shape, negative pressures along the contact surface will occur, resulting in an increased discharge. Figure 1 shows the variation of the coefficient as related to values of $\mathrm{H}_{\mathrm{e}} / \mathrm{H}_{\mathrm{o}}$, where $\mathrm{H}_{\mathrm{o}}$, is the actual head being considered.
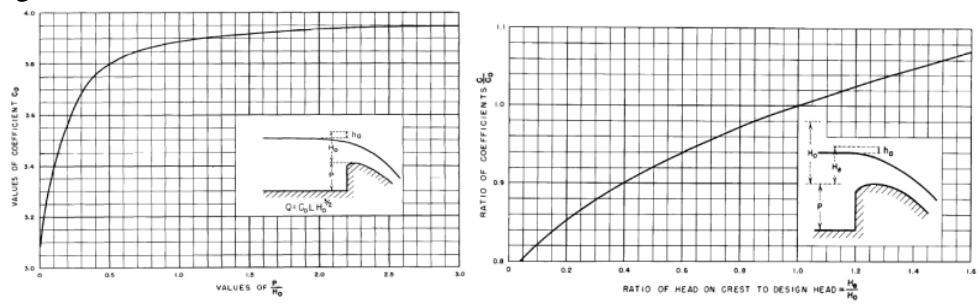

Figure 1. Determining discharge coefficient for flow over an ogee spillway

The general equation (1) for discharge over an ogee crested spillway is given as (USBR 1987):

$$
\mathrm{Q}=\mathrm{Co}_{0} * \mathrm{~L}^{*} \mathrm{H}_{0}{ }^{1.5}
$$

where $\mathrm{Q}$ is the total discharge, $\mathrm{L}$ is the lateral crest width, $\mathrm{C}_{\mathrm{o}}$ it the crest coefficient and $\mathrm{H}_{0}=$ total head upstream from crest.

In some cases, discharge coefficient, $C$ decreases because of submergence. Submergence can result excessive tail water depth. The effect of tail water submergence on discharge coefficient changes depending on degree of submergence defined by $\mathrm{h}_{\mathrm{d}} / \mathrm{H}_{\mathrm{e}}$ (shown in Figure 2).

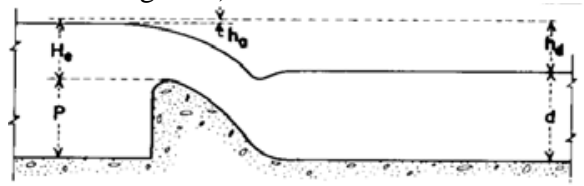

Figure 2. Tail water submergence

Two different flow type can be occur after ogee spillway, depending on the position of apron and downstream water surface. These situations are a submerged hydraulic jump and no jump may occur. When the submerged hydraulic jump occurs, the 


\section{INTERNATIONAL SYMPOSIUM "THE ENVIRONMENT AND THE INDUSTRY", SIMI 2018, PROCEEDINGS BOOK}

decrease in the discharge coefficient is caused by the back-pressure effect. Figure 3 shows the effect of downstream apron conditions on discharge coefficient.

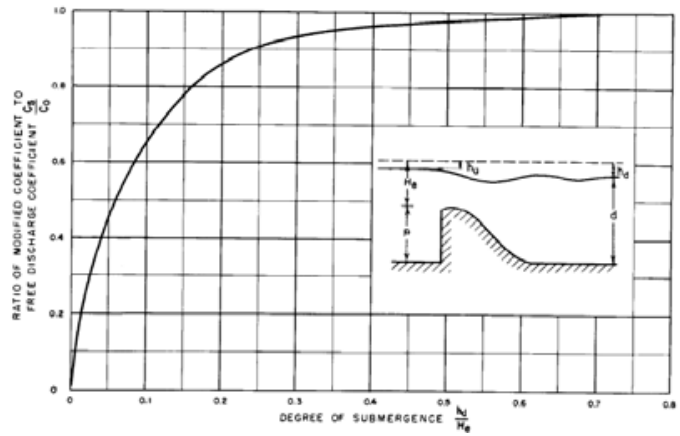

Figure 3. Ratio of discharge coefficients caused by tail water effects.

\section{Physical Modeling (Experimental Study)}

A physical model of a typical ogee spillway was fabricated from plexiglas and placed in open channel. Design head and crest height of ogee spillway are choose $\mathrm{H}_{0}=14,4 \mathrm{~cm}$ and $\mathrm{P}=28 \mathrm{~cm}$ respectively. General shape and dimensions of spillway can be seen in Figure 4.
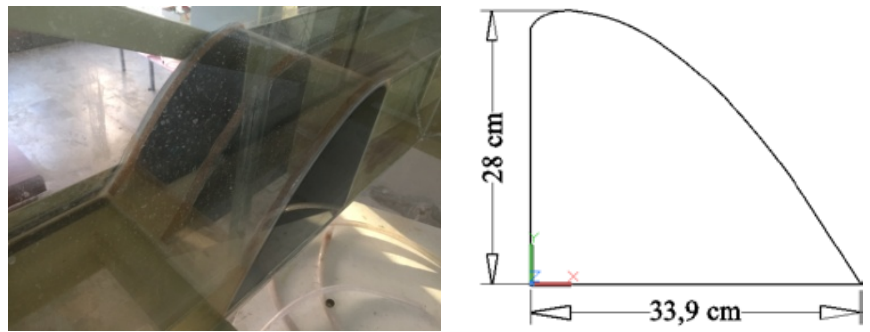

Figure 4. Ogee spillway used in experiments

The open channel which made of tempered glass is $6 \mathrm{~m}$ long, $0.6 \mathrm{~m}$ wide and $0.5 \mathrm{~m}$ height with zero tangential slope. The open channel is contracted to $0.3 \mathrm{~m}$ in region, to get higher heads over the ogee spillway. The open channel has a closed water loop system and flow to the channel is supplied from reservoir by pump. Pumps send water from reservoir-1 to reservoir-2 by pipes and water coming to reservoir-2 passes to channel. Discharges values are measured by Ultrasonic flow meter which placed on pipe coming from pumps. Total heads over the ogee spillway is determined with limnimetre. General view of the open channel system can be seen on Figure 5. 


\section{INTERNATIONAL SYMPOSIUM "THE ENVIRONMENT AND THE INDUSTRY", SIMI 2018, PROCEEDINGS BOOK}

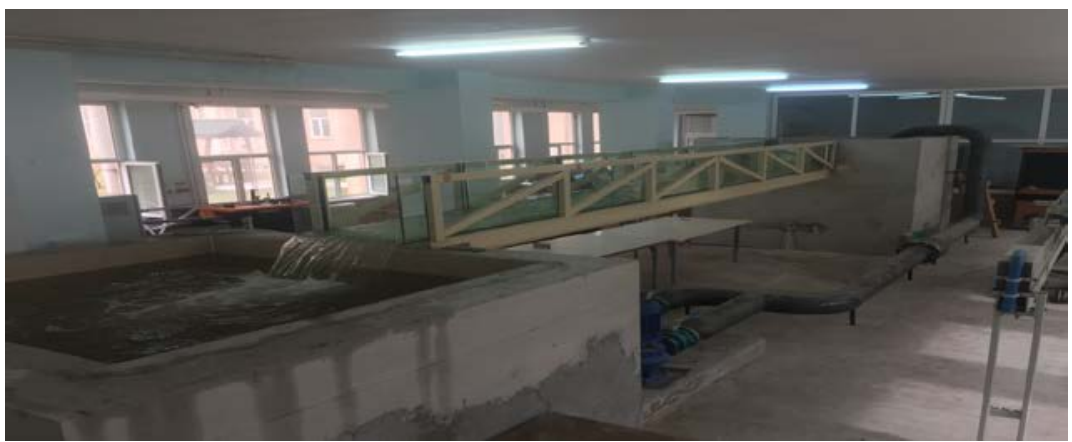

Figure 5. General view of the open channel system

\section{Numerical Modeling-Flow-3D}

The flow over the spillway was modeled by Flow-3D VOF-based CFD program and uses finite-volume approach to solve the Reynolds Averaged Navier Stokes (RANS) equations (Flow Science 2002). The program evaluates the location of the flow obstacles by implementing a cell porosity technique called as the fractional area/volume obstacle representation of FAVOR method. The computational domain is subdivided using Cartesian coordinates into a grid of variable-sized hexahedral cells. The general governing RANS (3) and the continuity equations (2) for an incompressible flow, including the FAVOR variables, are given by

$$
\begin{aligned}
& \frac{\partial}{\partial \mathrm{x}_{\mathrm{i}}}\left(\mathrm{u}_{\mathrm{i}} \mathrm{A}_{\mathrm{i}}\right)=0 \\
& \frac{\partial \mathrm{u}_{\mathrm{i}}}{\partial \mathrm{t}}+\frac{1}{\mathrm{~V}_{\mathrm{F}}}\left(\mathrm{u}_{\mathrm{j}} \mathrm{A}_{\mathrm{j}} \frac{\partial \mathrm{u}_{\mathrm{i}}}{\partial \mathrm{x}_{\mathrm{j}}}\right)=-\frac{1}{\mathrm{p}} \frac{\partial \mathrm{p}}{\partial \mathrm{x}_{\mathrm{i}}}+\mathrm{g}_{\mathrm{i}}+\mathrm{f}_{\mathrm{i}}
\end{aligned}
$$

where $u_{i}$ is the velocities in $x-y-z$ direction, $t$ is time, $A_{i}$ is fractional areas open to flow, $V_{F}$ is volume fraction of fluid in each cell, $\rho$ is density of fluid, $p$ is hydrostatic pressure, $g_{i}$ is gravitational forces, $f_{i}$ represent the Reynolds stresses.

Boundary conditions are determined in accordance with real experiments to represent physical model accurately in numerical model. There are six different $(+X$, $-\mathrm{X},+\mathrm{Y},-\mathrm{Y},+\mathrm{Z},-\mathrm{Z})$ boundaries on the main grid system because of flow domain is defined as a hexahedron. The upstream boundary condition $(-X)$, where water is supplied to channel and behave as reservoir, is defined hydrostatic pressure. This hydrostatic pressure is entered to Flow-3D as a height and it creates a total head over the ogee spillway. Therefore, varying total heads over the ogee spillway is provided by changing hydrostatic pressure value at (-X). Downstream boundary condition ($\mathrm{X})$, in other words end of the channel is defined as output. On the top boundary $(+Z)$ defined as atmospheric pressure and the bottom boundary (-Z) defined as wall. Side walls $(-Y,+Y)$ is defined symmetric.

In the numerical analysis two different mesh plane system were used. Firstly a mesh plane is generated to cover all system which have same dimensions with real physical model and the cell size of the mesh is chosen as $\Delta x=\Delta y=\Delta z=0,01 \mathrm{~m}$. Total number of the cells was calculated as 770000 . Analysis duration of numerical model 


\section{INTERNATIONAL SYMPOSIUM "THE ENVIRONMENT AND THE INDUSTRY", SIMI 2018, PROCEEDINGS BOOK}

takes too long time, when effect of the turbulence flow and total mesh number are considered. In experimental study, measurements are conducted for 22 different total heads and discharge values. One analysis takes 6 hour to complete and get steady-state solution. Therefore, mesh plane is contracted to middle of channel to make a solution with lower number of cells. However there are two questions arises "Will side walls affect the flow characteristic?" and "Will contracted mesh plane affect turbulent forces. To answer these questions, analyses conducted with two different mesh plane on model as seen Figure 6.

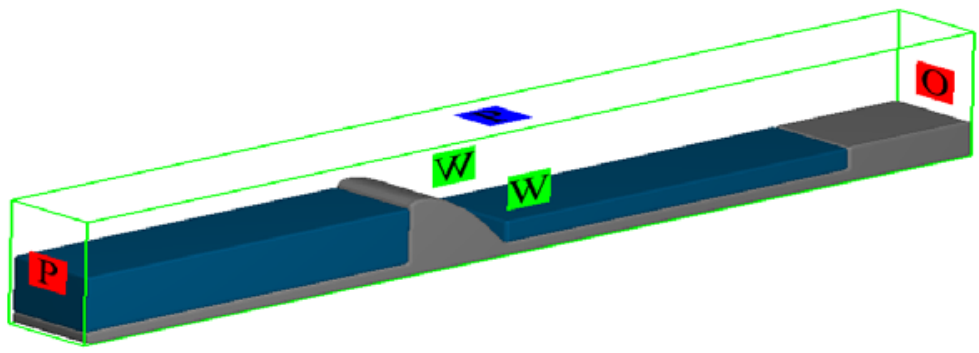

$x I_{x}$

a) Mesh solution- 1 with $0.3 \mathrm{~m}$ same as channel width

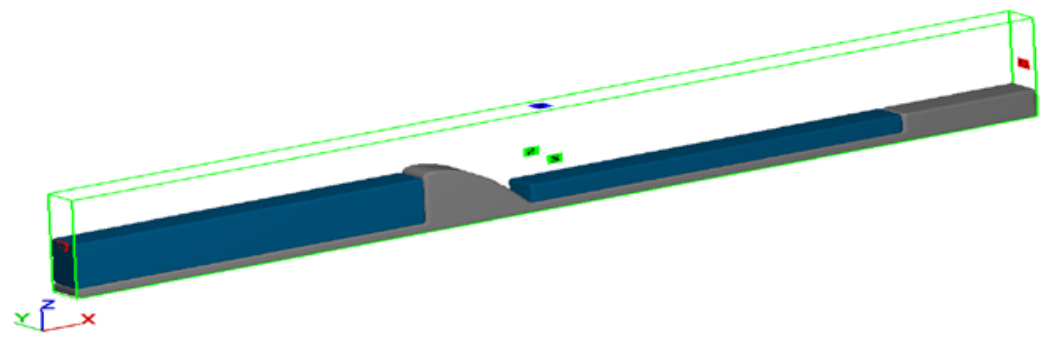

b) Mesh solution-2 with $0.1 \mathrm{~m}$ smaller than channel width

Figure 6. Two different mesh solutions

Second mesh plane is generated as cover middle section of channel. With of the second mesh plane is set $10 \mathrm{~cm}$ smaller than first mesh plane which has $30 \mathrm{~cm}$ width. The total number of cells in second mesh plane was calculated as 170500 . However side walls conditions $(-Y,+Y)$ is defined different from first mesh. Side wall conditions defined as Symmetry to remove effect of wall frictions on fluid flow.

\section{Results and Discussion}

The physical model carried out in the laboratory and the numerical model analyzed by Flow-3D were compared and discussed in terms of total heads $\left(\mathrm{H}_{\mathrm{e}}\right)$ over the ogee spillway, tail water heights and corresponding discharges (Q) (Figure 7). 


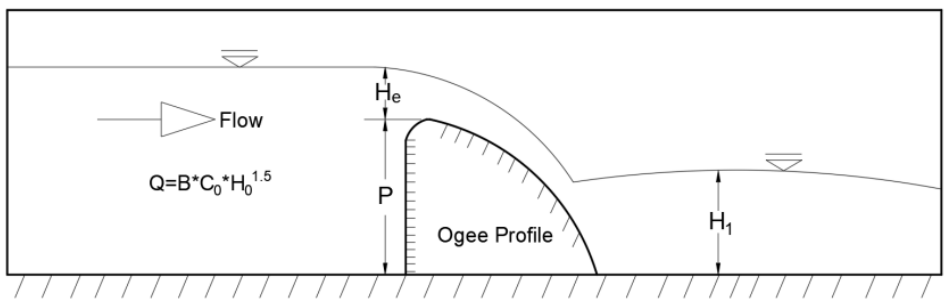

Figure 7. General schema of physical experiment and measurement points ( $\mathrm{He}_{\mathrm{e}}$ Total head over ogee, $\mathrm{H}_{1}$ : Tail water height)

The main objective of the comparison of the physical model with the numerical model was to determine how much numerical model is successful for predicting flow rate under effect of tail water submergence. Firstly, performances of two meshes systems are evaluated. According to results there is no significant difference between mesh systems in terms of total head and discharge values. By using contracted mesh planes, analysis time is shortened from 6 hours to 0.5 hours.

Table 1. Results obtained from models

\begin{tabular}{|c|c|c|c|c|c|}
\hline \multicolumn{3}{|c|}{ PHYSICAL MODEL } & \multicolumn{3}{|c|}{ NUMERICAL MODEL } \\
\hline $\mathrm{H}_{\mathrm{e}}(\mathrm{m})$ & $\mathrm{H}_{1}(\mathrm{~m})$ & $\mathrm{Q}_{\text {experimental }}(\mathrm{l} / \mathrm{s})$ & $\mathrm{H}_{\mathrm{e}}(\mathrm{m})$ & $\mathrm{H}_{1}(\mathrm{~m})$ & $\mathrm{Q}_{\text {model }}(\mathrm{l} / \mathrm{s})$ \\
\hline 0.024 & 0.113 & 1.98 & 0.017 & 0.124 & 1.67 \\
\hline 0.043 & 0.121 & 4.93 & 0.049 & 0.140 & 6.60 \\
\hline 0.064 & 0.131 & 9.80 & 0.059 & 0.151 & 9.06 \\
\hline 0.067 & 0.132 & 10.56 & 0.070 & 0.156 & 11.61 \\
\hline 0.081 & 0.142 & 14.17 & 0.079 & 0.163 & 13.74 \\
\hline 0.085 & 0.151 & 15.52 & 0.088 & 0.167 & 17.16 \\
\hline 0.091 & 0.152 & 17.88 & 0.098 & 0.180 & 20.43 \\
\hline 0.095 & 0.157 & 19.29 & 0.107 & 0.185 & 23.67 \\
\hline 0.099 & 0.161 & 21.00 & 0.117 & 0.204 & 27.24 \\
\hline 0.104 & 0.171 & 22.84 & 0.125 & 0.210 & 30.99 \\
\hline 0.110 & 0.166 & 24.18 & 0.135 & 0.223 & 35.04 \\
\hline 0.116 & 0.173 & 27.43 & 0.142 & 0.240 & 39.03 \\
\hline 0.123 & 0.183 & 30.10 & 0.154 & 0.250 & 43.29 \\
\hline 0.127 & 0.187 & 32.04 & & & \\
\hline 0.130 & 0.196 & 33.02 & & & \\
\hline 0.137 & 0.205 & 37.01 & & & \\
\hline 0.145 & 0.210 & 40.31 & & & \\
\hline 0.150 & 0.218 & 43.51 & & & \\
\hline 0.158 & 0.222 & 45.50 & & & \\
\hline
\end{tabular}




\section{INTERNATIONAL SYMPOSIUM "THE ENVIRONMENT AND THE INDUSTRY", SIMI 2018, PROCEEDINGS BOOK}

Table 1 shows total head over the ogee spillway and discharges values get from numerical and physical model. To make a more objective comparison between models results are showed on graph. Figure 8 shows comparison of total head vs. discharge values for both model and Figure 9 shows comparison of tail water depths vs. discharge values.

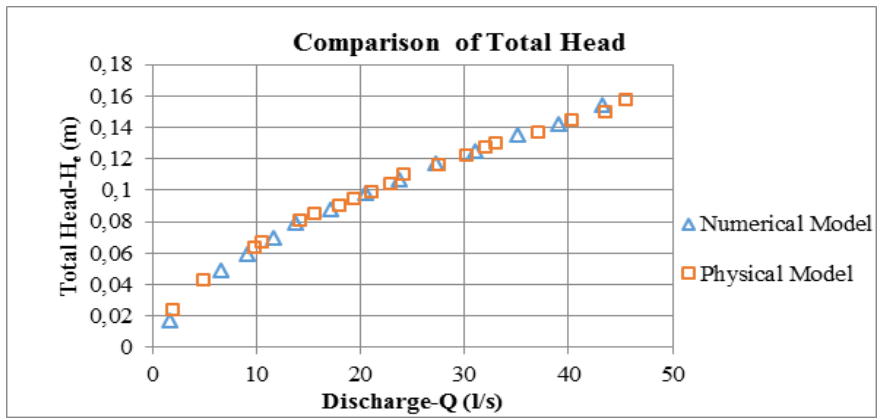

Figure 8. Comparison of total head results over ogee spillway get from numerical and physical model

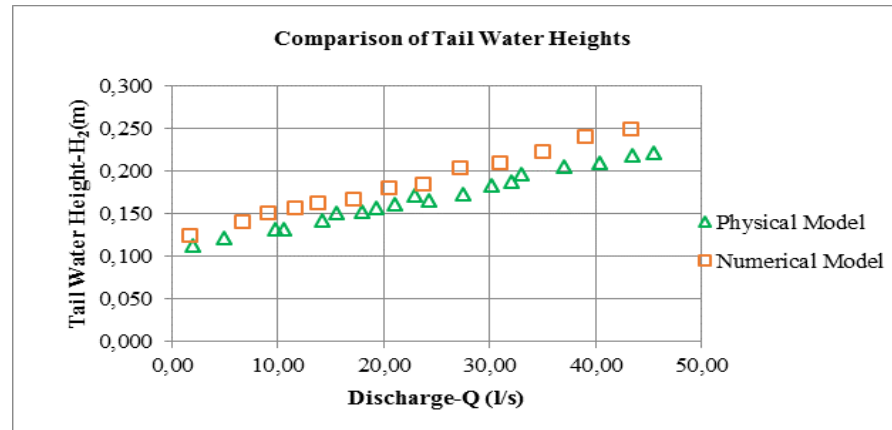

Figure 9. Comparison of tail water heights which causes submergence effect

Total head $\left(\mathrm{H}_{\mathrm{e}}\right)$ results given by numerical and physical model are compatible with each other. Flow-3D is very successful predicting total heads (He) and related discharge values. Also contracted mesh system worked very good to analyze physical model and provide time saving. However tail water results get from models don't show good agreement with each other as total heads show. Reason of these differences is high turbulences effects at this region. Measuring tail water flow depths in physical experiments are not correct one hundred percent because of waving of water surface. Although waving of water surface, Flow-3D give acceptable results and water surface profile (Figure 10). 


\section{INTERNATIONAL SYMPOSIUM "THE ENVIRONMENT AND THE INDUSTRY", SIMI 2018, PROCEEDINGS BOOK}

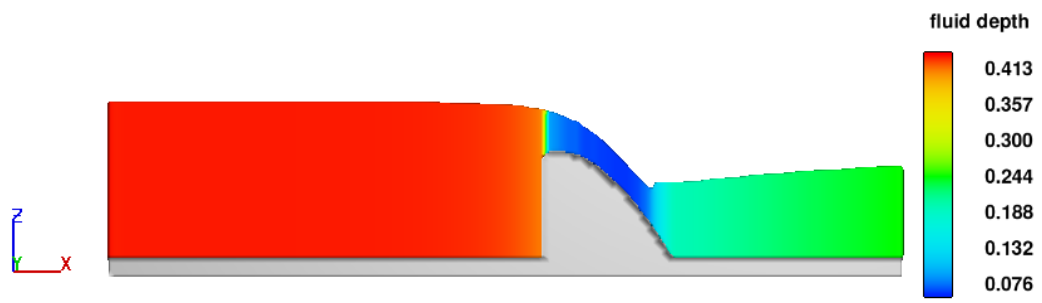

Figure 10. Water surface profile get from Flow-3D

\section{Conclusions}

Results obtained experiments showed that the discharge values obtained by Flow$3 \mathrm{D}$ were good agreement with physical model. This study showed that the numerical tools using RANS equations are sufficiently advanced to simulate a flow over an ogee spillway.

\section{References}

Bradley, JN 1952, Discharge Coefficients for Irregular Overfall Spillways, United States Department of the Interior Bureau of Reclamation (USBR), Denver, Colorado.

Cederstorm, M 1998, 'CFD modeling of spillway capacity- A comparison between hydraulic and mathematical models’, Dam Safety, Balkema, Rotterdam.

Flow Science 2002, Theory manual of Flow3-D, Flow Science, Los Alamos, NM.

Maynord, ST 1985, General Spillway Design, US Army Corps of Engineers (USACE), Washington DC.

United States Department of the Interior Bureau of Reclamation (USBR) 1987, Design of Small Dams, A Water Resources Technical Publication, Washington DC. 